\title{
Russian academy seeks a wider role in military research
}

can, New Mexico) - sometimes known as the Senator for Los Alamos - poised to chair the Senate Budget committee, the prospects for Los Alamos and Sandia nuclear weapons laboratories look bright.

The Commerce Department is likely to bear the brunt of Republican hostility to Clinton's technology policy. Almost every observer has singled out the fast-growing programmes of the National Institute of Standards and Technology as a priority target for Republican budget hawks.

In contrast, the National Aeronautics and Space Administration (NASA) may be the least affected by the power shift in Congress. Its strongest supporters are Republicans, but neither the money nor the political impetus exists to reverse the cuts planned in the agency's budget over the next five years.

Furthermore, if the prospects for federally funded technology prospects look gloomy, those for basic science - which Republicans have often favoured - may not be so bad.

Burt Richter, director of the Stanford Linear Accelerator Center (SLAC) in California and president of the American Physical Society, is one of those who expects there to be more emphasis on basic research. "The biggest pressure is going to fall on industry," he says.

Colin Macilwain programmes that involve government with

Moscow. In a move that has apparently won the backing of the Russian government but dismayed many outside observers, the Russian Academy of Sciences (RAS) has announced plans to set up a new constituent body to adopt responsibility for all government-supported applied science, in both the military and civilian sectors.

The surprise move, announced last month after a series of secret meetings, was proposed by Evgeny Velikhov, the academy's vice-president. There is confusion about the name of the new body - on some documents it is called the Russian Science and Technology Academy (RSTA) and on others the Russian Technical Academy.

According to some sources in Moscow, an official order setting up such an academy has already been signed by the first VicePremier of Russia, Oleg Soskovets. It will not be independent but will be an arm of the academy.

Such was the secrecy under which the plan was being prepared that neither Goskomimuschestvo (the State Property Committee), nor the Ministry of Sciences

$D$ tees go - those that write laws - the Labor and Human Resources Committee, previously the power-base of Senator Edward Kennedy (Democrat, Massachusetts), will go to the socially liberal Nancy Kassebaum (Republican, Kansas).

Energy and Natural Resources will probably be chaired by Frank Murkowski (Alaska), an oil and gas industry supporter. And the hitherto rather inactive science, technology and space subcommittee of the Commerce Committee could well be chaired by Conrad Burns (Montana), who shares vice-president Al Gore's enthusiasm for ensuring access-for-all on the information superhighway.

Changes in the House of Representatives are less predictable as the new speaker, Newt Gingrich (Republican, Georgia) and his right-wing supporters will not necessarily allow senior, liberal republicans to assume influential chairs automatically.

At the Appropriations Committee, for example conservative knives are already out for ranking member Joseph McDade (Pennsylvania), who is under indictment for alleged bribery but is still technically entitled to assume the chair.

Next in line is another centrist, John Myers (Indiana), whose fate could be something of a bellwether. If he is ousted by the right when the Republican caucus meets in early December to allocate the chairmanships, scientists' hopes of business as usual are unlikely to be fulfilled over the next two years.

On seniority grounds, John Myers would take the energy subcommittee at Appropriations, John Porter(Illinois), a long-time friend of $\mathrm{NIH}$, the labour, health and education subcommittee, and Jerry Lewis (California) would get VA-HUD. But Lewis is an old enemy of Gingrich's, and none of these positions is assured until after the caucus meets.

The same uncertainty hangs over the House authorization committees, with the added complication that jurisdictions may be changed to streamline the legislative process and cut staff. But one certainty is that Thomas Bliley (Virginia), the tobacco industry's most outspoken congressional supporter, will take over the health and environment subcommittee of Energy and Commerce.

The full Energy and Commerce Committee - which John Dingell built into a formidable power centre over decades may well be broken up in changes of jurisdiction that could also affect the Science, Space and Technology Committee, previously chaired by George Brown (Democrat, California).

A strengthened Science, Space and Technology committee could then be chaired by one of three possible candidates: Robert Walker (Pennsylvania), if he fails in a bid to become Republican whip; James Sensenbrenner (Wisconsin) if he fails to get the Judiciary Committee; or Sherwood Boehlert (New York), who actually wants the job of heading the only committee on Capitol Hill with a deep and sustained interest in science. was consulted, even though legally they should have been.

According to the draft charter of the RSTA, its aim is to unite research institutes, scientific centres, research and production associations, factories, laboratories and other organizations that currently fall within the jurisdiction of the State Committee of Defence Industries, the Ministry of Atomic Energy. It will also include other ministries and agencies involved in high technology research and development.

The first 200 academicians, forming the nucleus of the new academy, will be appointed. Another 200 will be elected at a later date in a system similar to that used in the RAS. The structure proposed for the RSTA is similar to that of RAS. But the RAS has not so far been able to solve two problems, namely the legal status of the new organization and its rights to property. The draft charter does not say whether the RSTA will be a state enterprise or a public association. Nor is it explicit about property rights.

But the RSTA will differ from RAS in at least one respect. The RAS is free of any supervision, but the activities of the new academy will be controlled by a board, headed by the first vice-premier of Russia. Other board members will include the president of the RAS, the deputy minister of economics, the minister of atomic energy, the minister of defence, and the chairman of the State Committee of Defence Industries. The chairman of the Federal Counterintelligence Service (formerly KGB), and the mayor of Moscow will also be members.

Vsevolod Medvedyev, a member of the RAS presidium, told a press conference in Moscow that the creation of the new academy was the only way to save the Russian military research and development complex from collapse. After the break-up of the former Soviet Union and its ministries, applied research in Russia, starved of financial support and often ineffective, went into rapid decline. Some research institutes were closed down, while others were deprived of their property and research equipment, or began to function merely as commercial real estate.

Yet many doubt the wisdom of the academy's move. Andrei Fonotov, the deputy ministry of science, says that the ministry's efforts to provide selective support to wellperforming enterprises is starting to show results - a conclusion confirmed at a meeting with foreign science policy experts last month in St Petersburg.

But Fonotov warns that the situation remains fragile, and that the planned "supermonopolization" of applied science may kill any chance of further progress by increasing bureaucratic controls and reducing flexibility.
Vladimir Pokrovsky 